\title{
Preparation of a Reference Material for the Determination of Hexavalent Chromium in Tap Water
}

\author{
Tetsuo InUi, ${ }^{\dagger}$ Hamana Shirota, and Shoji SAKao \\ Analytical Chemistry Group, Chemical Engineering Department, Kanagawa Institute of Industrial Science and \\ Technology, 705-1 Shimoimaizumi, Ebina, Kanagawa 243-0435, Japan
}

\begin{abstract}
We developed a reference material (RM) for the determination of hexavalent chromium $(\mathrm{Cr}(\mathrm{VI}))$ in tap water. The tap water RM was prepared by adding a $\mathrm{Cr}(\mathrm{VI})$ standard solution to the raw material without acidification, i.e., under the original $\mathrm{pH}$ conditions of 7.6, because the decrease in the concentration of $\mathrm{Cr}(\mathrm{VI})$ was observed when the tap water had been adjusted to $\mathrm{pH} 1$ with $\mathrm{HNO}_{3}$. The prepared tap-water RM (2 L) was packed in 10 fluororesin (PFA) bottles with an inside plug $(200 \mathrm{~mL}$ each). Each PFA bottle (Cr(VI)-containing tap water) was sealed in a reclosable poly bag and then stored at $5^{\circ} \mathrm{C}$ in a refrigerator. The tap water $\mathrm{RM}$ had a $\mathrm{Cr}(\mathrm{VI})$ concentration of $51 \mu \mathrm{g} \mathrm{L}{ }^{-1}$. The concentration of $\mathrm{Cr}(\mathrm{VI})$ was determined by diphenylcarbazide absorptiometry using a 100-mm quartz cell. The detection limit of $\mathrm{Cr}(\mathrm{VI})$ in the sample solution corresponding to three-times the standard deviation $(n=5)$ of blank values was $0.51 \mu \mathrm{g} \mathrm{L}^{-1}$. The homogeneity of $\mathrm{Cr}(\mathrm{VI})$ in the tap water RM was evaluated by an analysis of the variance after the Cochran test. There was no significant difference between the within-bottle and between-bottle variances of the analytical results, indicating that the tap water RM was sufficiently homogeneous. The stability of $\mathrm{Cr}(\mathrm{VI})$ in the tap water RM was investigated by monitoring the $\mathrm{Cr}(\mathrm{VI})$ concentration over a period of 6 months. The slope of the regression line of the $\mathrm{Cr}(\mathrm{VI})$ concentration versus the storage time did not significantly differ from zero, indicating that the tap water RM was stable for 6 months. The concentrations $\left(50-51 \mu \mathrm{g} \mathrm{L}^{-1}\right)$ of $\mathrm{Cr}(\mathrm{VI})$ in the tap water $\mathrm{RM}$ were in good agreement with the total chromium concentrations $\left(50-51 \mu \mathrm{g} \mathrm{L}^{-1}\right)$ obtained by atomic absorption spectrometry.
\end{abstract}

Keywords Hexavalent chromium, tap water, reference material, diphenylcarbazide absorptiometry, atomic absorption spectrometry

(Received July 9, 2019; Accepted August 20, 2019; Advance Publication Released Online by J-STAGE August 30, 2019)

\section{Introduction}

Cr is widely used in various industries, such as plating, pigment, stainless steel, and electrically heated wire. Although $\mathrm{Cr}$ has several oxidation states, $\mathrm{Cr}$ is present as trivalent chromium ( $\mathrm{Cr}(\mathrm{III}))$ and hexavalent chromium $(\mathrm{Cr}(\mathrm{VI}))$ in water. $\mathrm{Cr}(\mathrm{III})$ is considered to be one of the essential trace elements in the human body because it is deeply involved in the metabolism of glucose. On the other hand, $\mathrm{Cr}(\mathrm{VI})$ is highly toxic and exhibits carcinogenicity. A water quality standard and an environmental quality standard for $\mathrm{Cr}(\mathrm{VI})$ in Japan have been established at a concentration of $0.05 \mathrm{mg} \mathrm{L}^{-1}$. Therefore, it is important to monitor the $\mathrm{Cr}(\mathrm{VI})$ content of tap water and environmental water.

The Japanese Industrial Standard (JIS) K $0102^{1}$ has prescribed diphenylcarbazide (DPC) absorptiometry for the determination of $\mathrm{Cr}(\mathrm{VI})$ in water. This method is based on the selective reaction of $\mathrm{Cr}(\mathrm{VI})$ with DPC under acidic conditions to form a red-violet colored complex of $\mathrm{Cr}$ (III)-diphenylcarbazone, followed by measuring the absorbance at $540 \mathrm{~nm}$ using a spectrophotometer. Furusho et al. ${ }^{2}$ determined $\mathrm{Cr}(\mathrm{VI})$ in tap water by DPC absorptiometry with highly selective resin having molecular recognition ability. Ohmori and Saito $^{3}$ also

$\dagger$ To whom correspondence should be addressed.

E-mail: inui@kanagawa-iri.jp determined $\mathrm{Cr}(\mathrm{VI})$ in river water by absorptiometry using a DPC-containing thixotropic gel. Kataoka et al. ${ }^{4}$ determined $\mathrm{Cr}(\mathrm{VI})$ in mineral water by ion chromatography with postcolumn derivatization and spectrophotometric detection.

Certified reference materials (CRMs) are useful for confirming the validity of analytical results. The Japan Society for Analytical Chemistry (JSAC) developed river water CRMs (JSAC 0301-1, JSAC 0301-2, JSAC 0302). ${ }^{5}$ The National Metrology Institute of Japan (NMIJ) has issued a river water CRM (NMIJ CRM 7202-b) and a tap water CRM (NMIJ CRM 7203-a). ${ }^{6}$ The certified values of $\mathrm{Cr}$ in these CRMs are given as total chromium (T-Cr). In Japan, the water quality standard and the environmental quality standard are set as $\mathrm{Cr}(\mathrm{VI})$ (i.e., not $\mathrm{T}-\mathrm{Cr}$ ); therefore, a tap water CRM and an environmental water CRM containing $\mathrm{Cr}(\mathrm{VI})$ are necessary for the monitoring of water quality. However, a water-matrix CRM containing $\mathrm{Cr}(\mathrm{VI})$ has not yet been developed, because there is little knowledge on the stability of $\mathrm{Cr}(\mathrm{VI})$ in solution. For this reason, the development of a water-matrix CRM for the determination of $\mathrm{Cr}(\mathrm{VI})$ is required.

This paper describes the preparation of a reference material (RM) for the determination of $\mathrm{Cr}(\mathrm{VI})$ in tap water. Because the public water supplier must test the quality of tap water, tap water was selected as the matrix of RM. The tap water RM was prepared by adding a $\mathrm{Cr}(\mathrm{VI})$ standard solution to the raw material without acidification. The concentration of $\mathrm{Cr}(\mathrm{VI})$ was 
determined by DPC absorptiometry, which can directly determine only $\mathrm{Cr}(\mathrm{VI})$ in a mixture of $\mathrm{Cr}(\mathrm{III})$ and $\mathrm{Cr}(\mathrm{VI})$. Furthermore, the discussion is extended to (1) an enhancement of the sensitivity, (2) the effect of $\mathrm{HNO}_{3}$ addition, and (3) the homogeneity and stability of the tap water RM. The analytical results of $\mathrm{Cr}(\mathrm{VI})$ in the tap water $\mathrm{RM}$ were also validated by analyzing $\mathrm{T}-\mathrm{Cr}$ using atomic absorption spectrometry (AAS).

\section{Experimental}

Apparatus

A U-1800 spectrophotometer (Hitachi, Ltd., Tokyo, Japan) equipped with a 100-mm quartz cell was used for the determination of $\mathrm{Cr}(\mathrm{VI})$. The absorbance of the color-developed solution was measured at $540 \mathrm{~nm}$.

A SpectrAA-220Z atomic absorption spectrometer (Varian, Inc., Australia) equipped with a GTA110 graphite tube atomizer (Varian, Inc.) and an autosampler (Varian, Inc.) was used to determine the T-Cr. A Cr hollow cathode lamp was used as the light source, and the Zeeman effect was employed for a background correction. Ar was used as the carrier gas. A $10-\mu \mathrm{L}$ sample solution was dried at $85-120^{\circ} \mathrm{C}$ for $55 \mathrm{~s}$, ashed at $1000^{\circ} \mathrm{C}$ for $8 \mathrm{~s}$, and atomized at $2600^{\circ} \mathrm{C}$ for $4.8 \mathrm{~s}$. The integrated absorbance (peak area) of $\mathrm{Cr}$ was measured at $357.9 \mathrm{~nm}$ with a slit width of $0.2 \mathrm{~nm}$. The concentration of T-Cr was determined using a calibration curve with $\mathrm{Cr}(\mathrm{VI})$ standard solutions.

An SPS1200VR inductively coupled plasma atomic emission spectrometer (Seiko Instruments Inc., Tokyo, Japan) was used for the determination of $\mathrm{Ca}$ and $\mathrm{Mg}$. The operating conditions were as follows: RF power, $1.24 \mathrm{~kW}$; plasma gas flow rate, $16 \mathrm{~L} \mathrm{Ar} \mathrm{min}^{-1}$; auxiliary gas flow rate, $0.5 \mathrm{~L} \mathrm{Ar} \mathrm{min}^{-1}$; carrier

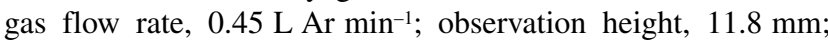
analytical line, $393.366 \mathrm{~nm}$ for $\mathrm{Ca}$ and $279.553 \mathrm{~nm}$ for $\mathrm{Mg}$. The concentrations of $\mathrm{Ca}$ and $\mathrm{Mg}$ were calculated using calibration curves with respective standard solutions.

An F-72 pH meter (Horiba, Ltd., Kyoto, Japan) was used for $\mathrm{pH}$ measurements. The $\mathrm{pH}$ meter was calibrated with standard solutions of $\mathrm{pH} 4$ (phthalate), $\mathrm{pH} 7$ (neutral phosphate), and pH 9 (borate). An Aquarius RFD342HA water distillation system (Advantec, Mfs, Inc., Tokyo, Japan) was used to prepare deionized water. An SA310 electric oven (Masuda Corp., Osaka, Japan) was used to dry $\mathrm{K}_{2} \mathrm{Cr}_{2} \mathrm{O}_{7}$ at $150^{\circ} \mathrm{C}$ for $1 \mathrm{~h}$. A Sanyo Medicool refrigerator (Sanyo Electric Co., Ltd., Osaka, Japan) was used to store the samples at $5^{\circ} \mathrm{C}$.

\section{Reagents and samples}

A $100 \mathrm{mg} \mathrm{L}^{-1} \mathrm{Cr}(\mathrm{VI})$ stock standard solution was prepared by dissolving the dried $\mathrm{K}_{2} \mathrm{Cr}_{2} \mathrm{O}_{7}$ (reference material for volumetric analysis, $>99.98 \%$ purity, Kanto Chemical Co., Inc., Tokyo, Japan) in deionized water. Stock standard solutions $\left(1000 \mathrm{mg} \mathrm{L}^{-1}\right)$ of $\mathrm{Ca}$ and $\mathrm{Mg}$ were purchased from Kanto Chemical Co., Inc. The calibration standards of $\mathrm{Cr}(\mathrm{VI}), \mathrm{Ca}$, and $\mathrm{Mg}$ were prepared by accurate dilution of the stock standard solutions with deionized water. A $10 \mathrm{~g} \mathrm{~L}^{-1}$ DPC solution as a coloring agent was prepared by dissolving 1,5-diphenylcarbonohydrazide (guaranteed reagent, Kanto Chemical Co., Inc.) in $100 \mathrm{~mL}$ of acetone containing a few drops of acetic acid. All other reagents used were of analytical-reagent grade.

Tap water was sampled at Ebina, Kanagawa, Japan. The tap water was filtered through a cellulose filter $(1 \mu \mathrm{m}$ pore size, Advantec, Toyo Roshi Kaisha, Ltd., Tokyo, Japan), and the filtrate was used as the raw material of RM. The concentrations of $\mathrm{Cr}(\mathrm{VI})$ and $\mathrm{T}-\mathrm{Cr}$ in the raw material were $<0.51 \mu \mathrm{g} \mathrm{L}^{-1}$ and $<0.53 \mu \mathrm{g} \mathrm{L}^{-1}$, respectively, whose values are detection limits corresponding to three-times the standard deviation $(n=5)$ of blank values. The raw material contained $20 \mathrm{mg} \mathrm{L}^{-1} \mathrm{Ca}$ and $5.5 \mathrm{mg} \mathrm{L}^{-1} \mathrm{Mg}$; that is, the hardness of water was $72 \mathrm{mg} \mathrm{L}^{-1}$. The $\mathrm{pH}$ of the raw material was 7.6.

\section{Preparation of tap water $R M$}

The tap water RM was prepared by adding $1 \mathrm{~mL}$ of a $100 \mathrm{mg} \mathrm{L}^{-1}$ $\mathrm{Cr}(\mathrm{VI})$ standard solution to a $2-\mathrm{L}$ volumetric flask, and then diluting to $2 \mathrm{~L}$ with the raw material without acidification, i.e., under the original $\mathrm{pH}$ conditions of 7.6. The prepared tap-water RM (2 L) was packed in 10 fluororesin (PFA) bottles with an inside plug (200 mL each), which were previously washed with $\mathrm{HNO}_{3}$ and rinsed with deionized water. Each PFA bottle $(\mathrm{Cr}(\mathrm{VI})$-containing tap water) was sealed in a reclosable poly bag and then stored at $5^{\circ} \mathrm{C}$ in a refrigerator until use.

\section{Determination of $\mathrm{Cr}(\mathrm{VI})$}

The determination of $\mathrm{Cr}(\mathrm{VI})$ was carried out using DPC absorptiometry according to JIS K 0102. ${ }^{1}$ A $25-\mathrm{mL}$ of sample solution was transferred into a $50-\mathrm{mL}$ volumetric flask, and then $2.5 \mathrm{~mL}$ of $1.8 \mathrm{~mol} \mathrm{~L}^{-1} \mathrm{H}_{2} \mathrm{SO}_{4}$ and $1 \mathrm{~mL}$ of a $10 \mathrm{~g} \mathrm{~L}^{-1} \mathrm{DPC}$ solution were successively added to the volumetric flask. After shaking for several seconds, the mixture was diluted to $50 \mathrm{~mL}$ with deionized water, and allowed to stand for $5 \mathrm{~min}$ for color development. The color-developed solution was transferred into a 100-mm quartz cell and introduced into a spectrophotometer. The absorbance of the solution was directly measured at $540 \mathrm{~nm}$. The concentration of $\mathrm{Cr}(\mathrm{VI})$ was calculated using a calibration curve, previously constructed with a series of $\mathrm{Cr}(\mathrm{VI})$ standard solutions.

\section{Results and Discussion}

\section{Enhancement of sensitivity}

This study aims to prepare a tap water RM with a $\mathrm{Cr}(\mathrm{VI})$ concentration of $50 \mu \mathrm{g} \mathrm{L}^{-1}$, the water quality standard for $\mathrm{Cr}(\mathrm{VI})$ in Japan, using DPC absorptiometry. An enhancement of the sensitivity of DPC absorptiometry is necessary for the precise determination of ppb levels of $\mathrm{Cr}(\mathrm{VI})$, because the dynamic range of DPC absorptiometry is from 2 to $50 \mu \mathrm{g}$ for $\mathrm{Cr}(\mathrm{VI}){ }^{1}$ In the absorptiometric analysis, a cell of $10-\mathrm{mm}$ path length is commonly used to measure the absorbance, although a commercially available cell is $1-100 \mathrm{~mm}$ in path length. ${ }^{7}$ According to Lambert's law, it is possible to enhance the sensitivity of DPC absorptiometry by using a cell of $100-\mathrm{mm}$ path length.

Figure 1 shows calibration curves of $\mathrm{Cr}(\mathrm{VI})$ using a $10-\mathrm{mm}$ quartz cell and a 100-mm quartz cell. A blank (deionized water) and four calibration standards $\left(5,10,25\right.$, and $50 \mu \mathrm{g} \mathrm{L}^{-1}$ of $\mathrm{Cr}(\mathrm{VI})$ ), both of which were prepared through the color development procedure of the DPC method, were used for constructing the calibration curves. The calibration curves of $\mathrm{Cr}(\mathrm{VI})$, established using $10-\mathrm{mm}$ and $100-\mathrm{mm}$ quartz cells, showed good linearity in the range of $5-50 \mu \mathrm{g} \mathrm{L}^{-1}$. The linear equations of the calibration curves of $\mathrm{Cr}(\mathrm{VI})$ were $Y=0.00083 \mathrm{X}$ $+0.034(r=0.9996)$ for $10-\mathrm{mm}$ quartz cell and $Y=0.0083 X+$ $0.040(r=0.9999)$ for $100-\mathrm{mm}$ quartz cell, where $X, Y$, and $r$ are the $\mathrm{Cr}(\mathrm{VI})$ concentration $\left(\mu \mathrm{g} \mathrm{L}^{-1}\right)$, the absorbance, and the correlation coefficient, respectively. The detection limits of $\mathrm{Cr}(\mathrm{VI})$ in the sample solution, corresponding to three-times the standard deviation $(n=5)$ of blank values, were $3.9 \mu \mathrm{g} \mathrm{L}^{-1}$ for 10 -mm quartz cell and $0.51 \mu \mathrm{g} \mathrm{L}^{-1}$ for $100-\mathrm{mm}$ quartz cell. The relative standard deviations (RSDs) of five independent measurements of $25 \mathrm{\mu g} \mathrm{L}^{-1}$ of $\mathrm{Cr}(\mathrm{VI})$ were $2.1 \%$ for $10-\mathrm{mm}$ 
quartz cell and $0.2 \%$ for $100-\mathrm{mm}$ quartz cell. The sensitivity (i.e., slope of calibration curve of $\mathrm{Cr}(\mathrm{VI})$ ) of DPC absorptiometry using a $100-\mathrm{mm}$ quartz cell was 10-times higher than that using a $10-\mathrm{mm}$ quartz cell. For this reason, a $100-\mathrm{mm}$ quartz cell was used throughout the study for the determination of ppb levels of $\mathrm{Cr}(\mathrm{VI})$.

\section{Effect of $\mathrm{HNO}_{3}$ addition}

In general, water-matrix CRMs for elemental analysis are acidified to $c a$. $\mathrm{pH} 1$ with $\mathrm{HNO}_{3}$ to prevent the hydrolysis of metal ions and the adsorption of metallic elements on the container walls during storage. However, $\mathrm{Cr}(\mathrm{VI})$ is present as $\mathrm{HCrO}_{4}^{-}$in an acidic solution, and $\mathrm{HCrO}_{4}^{-}$is unstable because of its high oxidizing power. ${ }^{8}$ Archundia et al..$^{9}$ and Pezzin et al. ${ }^{10}$ reported that low concentrations of $\mathrm{Cr}(\mathrm{VI})$ in diluted $\mathrm{HNO}_{3}$, $\mathrm{HCl}$, and $\mathrm{HClO}_{4}$ were reduced to $\mathrm{Cr}(\mathrm{III})$. Therefore, it is not desirable to preserve $\mathrm{Cr}(\mathrm{VI})$ under acidic conditions. On the other hand, $\mathrm{Cr}(\mathrm{VI})$ is present as $\mathrm{CrO}_{4}{ }^{2-}$ in solution above $\mathrm{pH} 7$, and $\mathrm{CrO}_{4}{ }^{2-}$ has a low oxidizing power compared with $\mathrm{HCrO}_{4}{ }^{-}$.

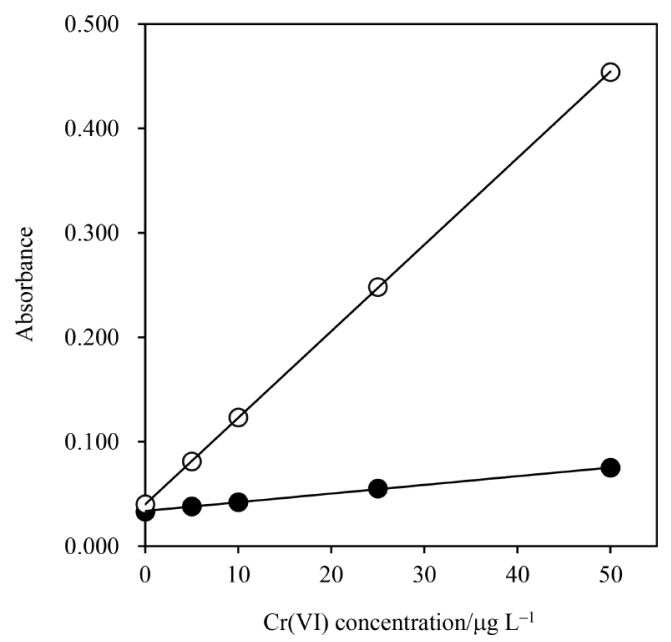

Fig. 1 Calibration curves of $\mathrm{Cr}(\mathrm{VI})$ using a $10-\mathrm{mm}$ quartz cell and a $100-\mathrm{mm}$ quartz cell $(\bigcirc)$.
Tap water is usually pH $7-8$; therefore, $\mathrm{Cr}(\mathrm{VI})$ may be stable in the tap water. In other words, a RM for the determination of $\mathrm{Cr}(\mathrm{VI})$ in tap water may be able to be prepared without acidification.

We first investigated the effect of $\mathrm{HNO}_{3}$ addition on the stability of $\mathrm{Cr}(\mathrm{VI})$ in tap water. Four tap water samples, each containing an initial $\mathrm{Cr}(\mathrm{VI})$ concentration of $50 \mu \mathrm{g} \mathrm{L} \mathrm{L}^{-1}$ in a PFA bottle with inside plug, were prepared with and without the addition of $\mathrm{HNO}_{3}$. They were stored at $5^{\circ} \mathrm{C}$ in a refrigerator and at room temperature in the dark. After preservation for $0,3,7$, 14,35 , and 90 days, the concentrations of $\mathrm{Cr}(\mathrm{VI})$ in the tap water were determined by DPC absorptiometry after 2-fold dilution of the water samples. Figure 2 shows the variations in the concentration of $\mathrm{Cr}(\mathrm{VI})$ in the tap water with and without the addition of $\mathrm{HNO}_{3}$ with the storage time. The concentration of $\mathrm{Cr}(\mathrm{VI})$ in the tap water of $\mathrm{pH} 1$ (i.e., with $\mathrm{HNO}_{3}$ addition) gradually decreased with an increase in the storage time at both $5^{\circ} \mathrm{C}$ and room temperature. After 90 days of storage at $\mathrm{pH} 1$, the concentrations of $\mathrm{Cr}(\mathrm{VI})$ in the tap water decreased by $20 \%$ at $5^{\circ} \mathrm{C}$ and by $29 \%$ at room temperature. The decreases in the concentrations of $\mathrm{Cr}(\mathrm{VI})$ in the tap water are due to the reduction of $\mathrm{Cr}(\mathrm{VI})$ to $\mathrm{Cr}(\mathrm{III})$, caused by the acidification of tap water, as reported by Archundia et al. ${ }^{9}$ and Pezzin et al. ${ }^{10}$ Furthermore, the reduction rate of $\mathrm{Cr}(\mathrm{VI})$ at room temperature $\left(\mathrm{ca} .20^{\circ} \mathrm{C}\right)$ was slightly higher than that at $5^{\circ} \mathrm{C}$, suggesting that the reduction reaction of $\mathrm{Cr}(\mathrm{VI})$ was accelerated by a temperature increase. In contrast, the concentration of $\mathrm{Cr}(\mathrm{VI})$ in the tap water of $\mathrm{pH}$ 7.6 (i.e., without $\mathrm{HNO}_{3}$ addition) did not decrease at both $5^{\circ} \mathrm{C}$ and room temperature during 90 days of storage. This result may be attributed to the difference in the oxidizing power of $\mathrm{Cr}(\mathrm{VI})$ between $\mathrm{pH} 1$ (i.e., $\mathrm{HCrO}_{4}^{-}$) and $\mathrm{pH} 7.6$ (i.e., $\mathrm{CrO}_{4}{ }^{2-}$ ). The results indicated that $\mathrm{Cr}(\mathrm{VI})$ in the tap water was stable at the original $\mathrm{pH}$ of 7.6. In this study, therefore, a RM for the determination of $\mathrm{Cr}(\mathrm{VI})$ in tap water was decided to be prepared by adding a $\mathrm{Cr}(\mathrm{VI})$ standard solution to the raw material without acidification.

\section{Homogeneity of the tap water RM}

RMs are required to be sufficiently homogeneous. The homogeneity of $\mathrm{Cr}(\mathrm{VI})$ in the tap water RM was evaluated by the analysis of variance after the Cochran test. ${ }^{11}$ For the

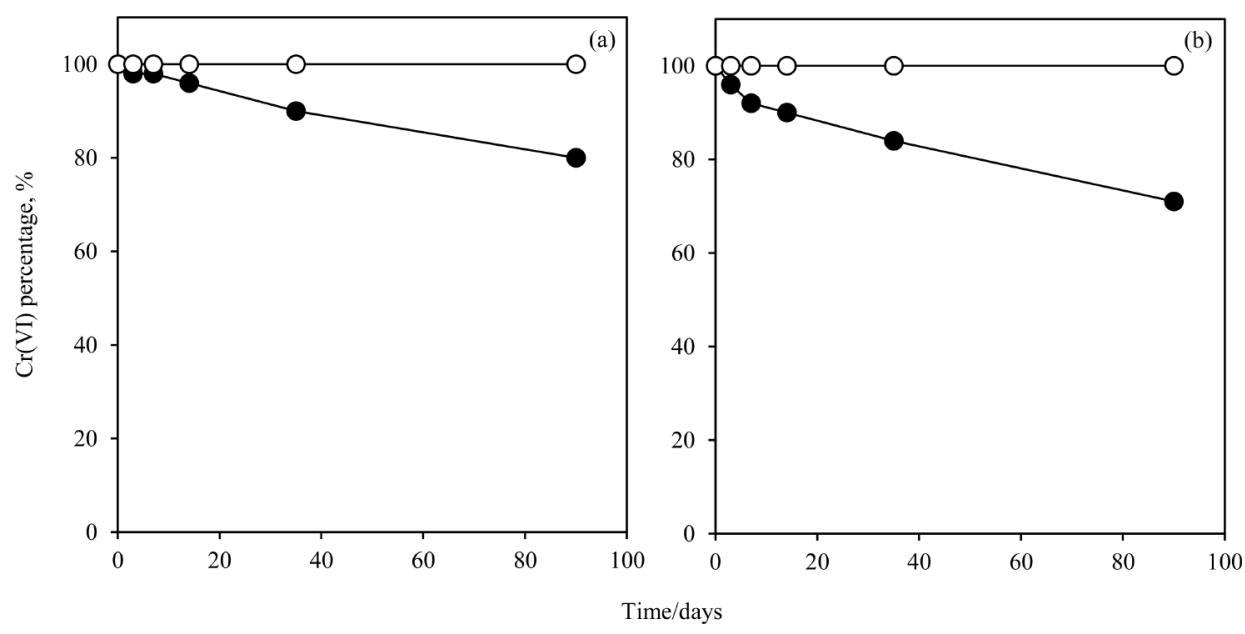

Fig. 2 Variations in the $\mathrm{Cr}(\mathrm{VI})$ concentration (initial concentration $=50 \mu \mathrm{g} \mathrm{L}^{-1}$ ) in the tap water with (๑) and without $(\bigcirc)$ the addition of $\mathrm{HNO}_{3}$ with the storage time: (a) $5^{\circ} \mathrm{C}$ in the refrigerator and (b) room temperature in the dark. The tap water samples with and without the addition of $\mathrm{HNO}_{3}$ were $\mathrm{pH} 1$ and $\mathrm{pH} 7.6$, respectively. 
Table 1 Results of a homogeneity test for $\mathrm{Cr}(\mathrm{VI})$ in tap water reference material by the analysis of variance after the Cochran test

\begin{tabular}{|c|c|c|c|c|c|}
\hline \multirow{2}{*}{$\mathrm{Cr}(\mathrm{VI})$ concentration $/ \mu \mathrm{g} \mathrm{L}^{-1}$} & \multirow{2}{*}{$\mathrm{RSD}^{\mathrm{b}}, \%$} & \multicolumn{2}{|c|}{ Cochran test } & \multicolumn{2}{|c|}{ Analysis of variance } \\
\hline & & Cochran's value & Critical value ${ }^{\mathrm{c}}$ & $F$-value & Critical value ${ }^{\mathrm{d}}$ \\
\hline 51 & 0.4 & 0.440 & 0.684 & 2.04 & 3.49 \\
\hline
\end{tabular}

a. Determined by diphenylcarbazide absorptiometry. b. Relative standard deviation, $\%(n=16)$. c. Level of significance, $\alpha=0.05$; number of groups, $k=4$; degree of freedom, $v_{\mathrm{x}}=3$. d. Level of significance, $\alpha=0.05$; degree of freedom for between-bottle, $v_{1}=3$; degree of freedom for within-bottle, $v_{2}=12$.

homogeneity test, 4 bottles were randomly selected from 10 bottles, and four independent measurements of the concentration of $\mathrm{Cr}(\mathrm{VI})$ were carried out for each bottle. The concentrations of $\mathrm{Cr}(\mathrm{VI})$ were determined by DPC absorptiometry after a 2-fold dilution. The results of the homogeneity test for $\mathrm{Cr}(\mathrm{VI})$ in the tap water RM are given in Table 1 . The average concentration of $\mathrm{Cr}(\mathrm{VI})$ was $51 \mu \mathrm{g} \mathrm{\textrm {L } ^ { - 1 }}$, and the $\mathrm{RSD}(n=16)$ of the concentration was $0.4 \%$.

First, the Cochran test was performed to verify the homoscedasticity of the within-bottle variance of the analytical results. Cochran's value $\left(C_{0}\right)$ was calculated using the following equation:

$$
C_{0}=S_{\mathrm{H}^{2}}^{2} / \sum_{\mathrm{i}} S_{\mathrm{i}}^{2}
$$

where $S_{\mathrm{H}}$ is the maximum standard deviation of the withinbottle, and $S_{\mathrm{i}}$ is the standard deviation of the within-bottle. The calculated Cochran's value was then compared with the critical value obtained from the statistical table under the following conditions: level of significance, $\alpha=0.05$; number of groups, $k=4$; degree of freedom, $v_{\mathrm{x}}=3$. When Cochran's value is lower than the critical value, the within-bottle variance is homoscedastic.

Next, the analysis of variance was performed to compare the between-bottle variance and the within-bottle variance of the analytical results. The between-bottle sum of square $\left(S_{\mathrm{sam}}{ }^{2}\right)$, within-bottle sum of square $\left(S_{\mathrm{an}}{ }^{2}\right)$, and $F$-value $(F)$ were calculated using the following equation:

$$
\begin{aligned}
& S_{\mathrm{sam}^{2}}=n \sum_{\mathrm{i}}\left(\bar{x}_{\mathrm{i}}-\bar{x}\right)^{2} /(m-1), \\
& S_{\mathrm{an}}{ }^{2}=\sum_{\mathrm{i}} \sum_{\mathrm{j}}\left(x_{\mathrm{ij}}-\bar{x}_{\mathrm{i}}\right)^{2} / m(n-1), \\
& F=S_{\mathrm{sam}^{2}} / S_{\mathrm{an}}{ }^{2},
\end{aligned}
$$

where $\bar{x}_{\mathrm{i}}$ is an average value of bottle $i, \bar{x}$ is an average of the whole value, $x_{\mathrm{ij}}$ is a $j$ th analytical value of bottle $i, m$ is the number of bottles, and $n$ is the number of measurements. The calculated $F$-value was then compared with the critical value obtained from table of the $F$-distribution under the following conditions: level of significance, $\alpha=0.05$; degree of freedom for between-bottle, $v_{1}=3$; degree of freedom for within-bottle, $v_{2}=12$. When $F$-value is lower than the critical value, there is no significant difference between the within-bottle variance and the between-bottle variance of the analytical results.

As a result, both Cochran's value and $F$-value were lower than the critical values (Table 1). In other words, the within-bottle variance was homoscedastic, and there was no significant difference between the within-bottle and between-bottle variances of the analytical results. From these results, we concluded that the tap water RM was sufficiently homogeneous.
Table 2 Results of a stability study for $\mathrm{Cr}(\mathrm{VI})$ in tap water reference material over a period of 6 months

\begin{tabular}{cccc}
\hline $\begin{array}{c}\text { Time/ } \\
\text { month }\end{array}$ & $\begin{array}{c}\text { Cr(VI) } \\
\text { concentration } / \\
\mu \mathrm{g} \mathrm{L}^{-1}\end{array}$ & $\begin{array}{c}\mathrm{T}-\mathrm{Cr} \\
\text { concentration } / \\
\mu \mathrm{g} \mathrm{L}^{-1}\end{array}$ & $\mathrm{pH}$ \\
\hline 0 & 50 & 51 & 7.6 \\
1 & 51 & 50 & 7.6 \\
3 & 50 & 51 & 7.6 \\
6 & 50 & 51 & 7.6 \\
\hline
\end{tabular}

a. Determined by diphenylcarbazide absorptiometry.

b. Determined by atomic absorption spectrometry.

\section{Stability of the tap water RM}

RMs are also required to be sufficiently stable. The stability of $\mathrm{Cr}(\mathrm{VI})$ in the tap water RM was investigated by monitoring the $\mathrm{Cr}(\mathrm{VI})$ concentration over a period of 6 months. For the stability study, 4 bottles were selected from the remaining 6 bottles, and $\mathrm{Cr}(\mathrm{VI}), \mathrm{T}-\mathrm{Cr}$, and $\mathrm{pH}$ were determined after preservation for $0,1,3$, and 6 months. The concentrations of $\mathrm{Cr}(\mathrm{VI})$ were determined by DPC absorptiometry after a 2-fold dilution. The results of the stability study for $\mathrm{Cr}(\mathrm{VI})$ in the tap water RM are given in Table 2. The concentrations (50 - 51 $\left.\mu \mathrm{g} \mathrm{L}^{-1}\right)$ of $\mathrm{Cr}(\mathrm{VI})$ in the tap water $\mathrm{RM}$ were in good agreement with those $\left(50-51 \mu \mathrm{g} \mathrm{L}^{-1}\right)$ of T-Cr obtained by AAS, suggesting that $\mathrm{Cr}(\mathrm{VI})$ in the tap water RM was not reduced to $\mathrm{Cr}(\mathrm{III})$. In addition, the tap water RM showed a constant $\mathrm{pH}$ value of 7.6, indicating that $\mathrm{Cr}(\mathrm{VI})$ was present as $\mathrm{CrO}_{4}{ }^{2-}$ in the tap water RM. Furthermore, precipitates and algae were not visually observed in the tap water RM during 6 months of storage.

The stability of the tap water RM was evaluated using a linear regression model $\left(y=b_{1} x+b_{0}\right)$ according to JIS Q 0035. ${ }^{12}$ If $\left|b_{1}\right|<t_{0.95, \mathrm{n}-2} \times s\left(b_{1}\right)$, the slope does not significantly differ from zero; that is, there is no instability. Here, $b_{1}$ is the slope, $b_{0}$ is the intercept, $t_{0.95, \mathrm{n}-2}$ is the Student's $t$-factor for $n-2$ degrees of freedom and $p=0.95$ (95\% confidence level), and $s\left(b_{1}\right)$ is the uncertainty associated with the slope. In Table 2 , the concentration of $\mathrm{Cr}(\mathrm{VI})$ and the storage time are plotted as the $y$-axis $\left(\mu \mathrm{g} \mathrm{L}^{-1}\right)$ and $x$-axis (months), respectively. When the regression analysis was performed, $b_{1}$ was -0.0714 and $s\left(b_{1}\right)$ was 0.1237 . In this case, the Student's $t$-factor is equal to 4.30 . As a result, the slope of the regression line of the $\mathrm{Cr}(\mathrm{VI})$ concentration versus the storage time did not significantly differ from zero, and hence, no instability was observed. Consequently, we concluded that the tap water RM was stable for 6 months. In the future, the stability of $\mathrm{Cr}(\mathrm{VI})$ in the tap water $\mathrm{RM}$ will be continuously monitored. 


\section{Conclusions}

A RM for the determination of $\mathrm{Cr}(\mathrm{VI})$ in tap water was developed using DPC absorptiometry. The tap water RM was prepared by adding a $\mathrm{Cr}(\mathrm{VI})$ standard solution to the raw material without acidification. A $100-\mathrm{mm}$ quartz cell was used to enhance the sensitivity of DPC absorptiometry. The concentration of $\mathrm{Cr}(\mathrm{VI})$ in the tap water $(\mathrm{pH} 1)$ with the addition of $\mathrm{HNO}_{3}$ decreased, whereas that of $\mathrm{Cr}(\mathrm{VI})$ in the tap water ( $\mathrm{pH}$ 7.6) without the addition of $\mathrm{HNO}_{3}$ did not decrease. This study revealed that $\mathrm{Cr}(\mathrm{VI})$ in tap water is stable at the original $\mathrm{pH}$ of 7.6. The results of the analysis of variance after the Cochran test indicated that the tap water RM was sufficiently homogeneous. In addition, the results of the regression analysis indicated that the tap water RM was stable for 6 months. The tap water RM with a $\mathrm{Cr}(\mathrm{VI})$ concentration of $51 \mu \mathrm{g} \mathrm{L}^{-1}$, nearly equal to the water quality standard $\left(50 \mu \mathrm{g} \mathrm{L}^{-1}\right)$ for $\mathrm{Cr}(\mathrm{VI})$ in Japan, can be used for confirming the validity of analytical results of $\mathrm{Cr}(\mathrm{VI})$ in tap water.

\section{References}

1. JIS K 0102, "Testing Method for Industrial Wastewater",
2016, Japanese Industrial Standards Committee, Tokyo.

2. Y. Furusho, M. Ono, M. Yamada, T. Kitade, and S. Motomizu, Bunseki Kagaku, 2009, 58, 147.

3. K. Ohmori and T. Saito, Bunseki Kagaku, 2009, 58, 801.

4. Y. Kataoka, T. Watanabe, K. Hayashi, R. Ozawa, K. Takizawa, and H. Akiyama, Shokuhin Eiseigaku Zasshi, 2017, 58, 275

5. A. Kawase, K. Ohashi, I. Akabane, T. Kuroiwa, M. Murayama, H. Yoshimura, J. Yoshinaga, M. Uemoto, A. Ono, K. Kakita, and M. Sakata, Bunseki Kagaku, 2006, 55, 875 .

6. Y. Zhu, T. Narukawa, K. Inagaki, S. Miyashita, T. Kuroiwa, T. Ariga, I. Kudo, M. Koguchi, S. W. Heo, J. K. Suh, K. S. Lee, Y. H. Yim, and Y. Lim, Anal. Sci., 2017, 33, 403.

7. M. Kamaya, Bunseki, 2008, 4, 158.

8. J. Kotaś and Z. Stasicka, Environ. Pollut., 2000, 107, 263.

9. C. Archundia, P. S. Bonato, J. F. Lugo Rivera, L. C. Mascioli, K. E. Collins, and C. H. Collins, Sci. Total. Environ., 1993, 130, 231.

10. S. H. Pezzin, J. F. Lugo Rivera, C. H. Collins, and K. E. Collins, J. Braz. Chem. Soc., 2004, 15, 58.

11. H. Tanaka, Bunseki, 2010, 4, 168.

12. JIS Q 0035, "Reference Materials-General and Statistical Principles for Certification", 2008, Japanese Industrial Standards Committee, Tokyo. 